\title{
Memórias e disputas: o caso Edson Luís e a memória de 1968
}

\author{
Leylianne Alves VIEIRA ${ }^{1}$
}

Resumo:

Este artigo tem como objetivo analisar a construção das memórias em torno de Edson Luís de Lima Souto, estudante assassinado em 1968, no Rio de Janeiro. Edson Luís não participou do movimento estudantil e foi morto durante uma manifestação por melhorias no restaurante Calabouço. Personagem até então desconhecido, é alçado à categoria de mártir ao ser o primeiro estudante morto publicamente por militares durante a ditadura. Foram selecionados como material para análise duas edições da Folha de S. Paulo e uma do Jornal do Brasil, publicadas no dia seguinte à morte, e três livros: Calabouço 1968: o cerco das trevas, de Josué Diniz; 1968: o ano que não terminou, de Zuenir Ventura; e 1968: eles só queriam mudar o mundo, de Regina Zappa e Ernesto Soto. Em um cenário de disputa pela memória, Edson Luís faz parte de uma trama de marcações emocionais que o alçam à memória coletiva (HALBWACHS, 2003) e fazem dele um representante da resistência à violência do regime militar.

Palavras-chave: Memória. Jornalismo. Ditadura. 1968. Edson Luís.

\section{Memories and disputes: the Edson Luís case and the memory of 1968}

\begin{abstract}
:
This article aims to analyze the construction of memories around Edson Luís de Lima Souto, a student murdered in 1968, in Rio de Janeiro. Edson Luís did not participate in the student movement and was killed during a demonstration for improvements in the Calabouço restaurant. An unknown character until then, he is raised to the category of martyr for being the first student publicly killed by military during the dictatorship. Two editions of Folha de S. Paulo and one of Jornal do Brasil, published the day after death, and three books are chosen as material for analysis: Calabouço 1968: o cerco das trevas, by Josué Diniz; 1968: o ano que não terminou, by Zuenir Ventura; and 1968: eles só queriam mudar o mundo, by Regina Zappa and Ernesto Soto. In a scenario of dispute for memory, Edson Luís is part of a plot of emotional markings that lift him to collective memory (HALBWACHS, 2003) and make him a representative of the military regime's resistance to violence.
\end{abstract}

Keywords: Memory. Journalism. Dictatorship. 1968. Edson Luís.

\section{Memorias y disputas: el caso Edson Luís y la memoria de 1968}

\begin{abstract}
Resumen:
Este artículo tiene como objetivo analizar la construcción de memorias alrededor de Edson Luís de Lima Souto, un estudiante asesinado en 1968 en Río de Janeiro. Edson Luís no participó en el movimiento estudiantil y fue asesinado en medio a una protesta por mejorías en el restaurante Calabouço. Hasta entonces de carácter desconocido, es elevado a la categoría de mártir como el primer estudiante asesinado públicamente por los militares durante la dictadura. Dos ediciones de Folha de S. Paulo y una de Jornal do Brasil, publicadas al día siguiente de la muerte, y tres libros fueron seleccionados como material para el análisis: Calabouço 1968: O cerco das trevas, de Josué Diniz, 1968: O ano que não terminou, de Zuenir Ventura y 1968: eles só queriam mudar o mundo, de Regina Zappa y Ernesto Soto. En un escenario de disputa por la memoria, Edson Luís es parte de una trama de huellas emocionales que lo elevan a la memoria colectiva (HALBWACHS, 2003) y lo convierten en un representante de la resistencia a la violencia del régimen militar.
\end{abstract}

Palabras clave: Memoria. Periodismo. Dictadura. 1968. Edson Luís.

\footnotetext{
${ }^{1}$ Doutora em Comunicação pela Universidade Federal de Minas Gerais. Pesquisadora do Instituto Nacional de Ciência e Tecnologia em Políticas Públicas e Desenvolvimento Territorial.E-mail: leylianne.av@gmail.com.
} 


\section{Introdução}

A década era 1960, o ano era 1968. Um período emblemático na história mundial, muitas vezes lembrado pela pujança que assumiu o movimento estudantil, que ganhou força em países como França, México, Alemanha, Itália, Japão e, também, no Brasil. Desde a dissolução da União Nacional dos Estudantes (UNE) e a destruição do edifício que ocupava no Aterro do Flamengo, no Rio de Janeiro, em $1^{\text {o }}$ de abril de 1964 , mesmo dia do golpe militar, o movimento vinha buscando formas de atuar, na ilegalidade.

Com o início da ditadura, os encontros de estudantes passaram a acontecer às escondidas, muitas vezes em porões de igrejas, acobertados por padres. Em 1968, estudantes e operários buscavam ser escutados pelos ouvidos surdos da ditadura: ocupavam as ruas, faziam passeatas, destruíam carros oficiais. Pedras e bolas de gude contra armas de fogo e cavalarias. Foi em meio a uma dessas manifestações, em que estudantes lutavam pela educação do país e, em alguma medida, contra a ditadura, que um deles foi morto. Sua camisa ensanguentada foi utilizada como bandeira de um movimento que ganhava força, ao mesmo tempo em que, contraditoriamente, começava a ser asfixiado pela repressão. Edson Luís de Lima Souto, secundarista, é lembrado por ter sido um dos primeiros casos de estudante morto publicamente durante a ditadura, um nome que se repete sempre que rememoramos aquele regime no Brasil. Após Edson Luís, muitos outros estudantes foram mortos, nos porões da ditadura ou no meio da rua, em nome da ordem e da segurança nacional.

Neste artigo, temos como objetivo realizar uma aproximação em relação ao caso Edson Luís, buscando entender de que forma se deu a construção da memória, por meio da mídia, em torno desse estudante. Analisaremos textos veiculados por jornais na época do acontecimento, a saber, Folha de S. Paulo e Jornal do Brasil, ambos com acervos online disponíveis, e livros jornalísticos e de memórias publicados posteriormente. Pretendemos perceber qual o papel que esse personagem possui no contexto de batalhas pela memória que se instaurou nos últimos anos, fazendo interagir, para fins de análise, as narrativas históricas e comunicacionais.

Neste percurso, começaremos traçando algumas linhas sobre a relação que se instituiu no Brasil e na América Latina entre a memória e os governos repressivos, tendo como principal base de trabalho os textos de Elizabeth Jelin e Maurice Halbwachs. Em seguida, passaremos à exposição do caso, buscando perceber o papel da mídia nesse contexto, bem como daqueles que se utilizam do texto jornalístico como forma de gravar memórias que já 
foram revistas e revisitadas. Por fim, traçaremos algumas considerações acerca da forma como lidamos com a memória da ditadura no país e o papel que a mídia possui nessa batalha.

\section{A memória e as ditaduras}

O ano de 1968 acolheu expressivos movimentos políticos e culturais no país e no mundo. No caso brasileiro, os fatos se desenrolam em meio e em resposta ao governo militar, ditatorial. Faz-se importante lembrarmos que, apesar de aquele ser um período de movimentações estudantis em todo o mundo, as que aqui se desenvolviam responderiam a um governo que não tinha interesse em dar voz ou espaço aos cidadãos. O ano de 1968 possui certo caráter de centralidade em meio à ditadura militar: ações que até aquele momento eram justificadas como pertencentes a um período de transição em prol da democracia passam a ser percebidas como reflexos de um governo autoritário.

A memória de 1968 é uma construção que se dá por meio de relatos, testemunhos, textos oficiais, para citar apenas algumas das formas que podem ser acionadas para a construção de uma narrativa. Esses fragmentos de memória vão entrar, gradualmente, em diálogo, ou disputa, com os textos oficiais.

Na proporção em que determinados sujeitos se utilizam da memória e do testemunho a fim de reconstituírem momentos que marcaram suas biografias, contribuem, gradualmente, para a construção e reconstrução, em um processo contínuo, da memória. Do ponto de vista do sujeito, lembrar não é reviver, mas, sim, refazer, reconstruir, repensar, a partir de um arcabouço de observações, as experiências do passado (HALBWACHS, 2003). Não existem memórias estritamente individuais, posto que necessitamos do compartilhamento de noções entre os sujeitos de uma mesma sociedade para a construção das memórias.

Quem se propõe a escrever baseado na memória daquilo que vivenciou faz jus, portanto, ao dever que socialmente se impõe de preservar parte da memória, produzindo fragmentos que vão compor as memórias coletivas (HALBWACHS, 2003). Tão logo a narrativa é registrada, passa a fazer parte de uma memória construída e compartilhada (BABO-LANÇA, 2012). As memórias são fruto daquilo que marcou a experiência, dizem respeito a uma marcação emocional do passado. As memórias surgem como uma tentativa de impedir que os erros sejam cometidos novamente. $\mathrm{O}$ ato de testemunhar, neste sentido, também carrega uma marcação emocional. Do testemunho à memória, porém, existe um transcurso que não se faz uniforme: o processo de interação e experiência interfere na forma 
como o sujeito olha, avalia e narra as próprias memórias.

O texto escrito carrega indícios de como o autor representa o mundo, suas vivências, suas experiências. As narrativas estarão impregnadas de referências ao contexto do qual fazem parte. As ideologias políticas, os movimentos culturais, as inter-relações com os demais personagens da época, todos estes aspectos poderão ser encontrados por meio de vestígios deixados pela construção narrativa do texto. A narrativa pressupõe que os fatos narrados possuam uma sequência e, mais que isso, uma razão para estarem sendo narrados, portanto, um passado que os justifique.

A memória tem um papel central em relação à construção das narrativas. A discussão sobre ela tem início a partir da noção de tempo. Vivenciamos e construímos nossas narrativas no dia a dia. No entanto, ao evocarmos estas memórias, devemos ter consciência de algo bastante significativo: “[...] a representação das coisas evocada pela memória individual não é mais do que uma forma de tomarmos consciência da representação coletiva relacionada às mesmas coisas [...]" (HALBWACHS, 2003, p. 61). A memória convocada pelo indivíduo e aquela acionada pelos grupos dos quais ele participa estão em contínua interação. Halbwachs (2003) afirma que somos um eco daquilo que nos envolve, mesmo que não tenhamos consciência disso. Cada enunciação, portanto, se vê como a reverberação de várias outras.

De acordo com Pollak (1989, p. 4), as pesquisas sobre a memória passam, de uma perspectiva construtivista, a "[...] analisar como os fatos sociais se tornam coisas, como e por quem eles são solidificados e dotados de duração e estabilidade. [...] essa abordagem irá se interessar portanto pelos processos e atores que intervêm no trabalho de constituição e de formalização das memórias". Aqui, voltamos o nosso olhar para o valor desses sujeitos e ações no quadro social de uma memória em disputa.

Jelin (2002) afirma que a memória insiste em sua presença, não ficando presa ao passado, de forma que nosso passado ditatorial recente faz parte do presente. É no campo da linguagem que se situa o cenário de luta pela representação desse passado, envolvendo, ainda segundo Jelin (2002), questões de poder, legitimidade e reconhecimento.

A disputa na qual a memória está envolvida é composta por um quadro de elementos sobre os quais não temos domínio, individualmente. Pollak (1989) afirma que poderíamos tratar de "memórias enquadradas", termo que, segundo o autor, seria mais adequado que "memórias coletivas", uma vez que põem em jogo os sentidos das identidades individuais e de grupo, ao mesmo tempo em que dá a ver elementos das estruturas social e institucional de 
uma determinada sociedade, das opções tomadas em relação à história e ao presente:

O trabalho de enquadramento da memória se alimenta do material fornecido pela história. Esse material pode sem dúvida ser interpretado e combinado a um sem-número de referências associadas; guiado pela preocupação não apenas de manter as fronteiras sociais, mas também de modificá-las, esse trabalho reinterpreta incessantemente o passado em função dos combates do presente e do futuro (POLLAK, 1989, p. 10).

Do acontecimento à memória temos um espaço de tempo a ser percorrido e, sobretudo, experienciado. Eles precisam ser digeridos, em primeira instância, por aqueles que o vivenciaram. Em outros termos, "o acontecimento continua assim a acontecer ou a devir para além da sua ocorrência espaciotemporal e empírica, durante o tempo que dura o seu campo de possíveis, a modificação de situações, a provação e a acção daqueles a quem acontece" (BABO-LANÇA, 2005, p. 89). Os indivíduos que observam a partir de uma distância espacial ou temporal são sensibilizados de forma mais amena que aqueles que participam dos eventos ou que o associam com o sentimento de perda. No entanto, a sensibilização acontece independentemente da localização dos sujeitos, desde que o acontecimento ainda possa ser sentido em meio às tramas sociais. Após estas primeiras definições teóricas, aproximemo-nos do caso aqui elencado e percebamos como os testemunhos e as mídias vêm atuando na construção da memória de 1968.

\section{Edson Luís: entre estudante e símbolo da luta contra a ditadura}

"Estudante morto em choque no Rio" (ESTUDANTE.., 1968, p. 01). "Assassinato leva estudantes à greve nacional" (ASSASSINATO..., 1968, p. 01). "Polícia de Negrão chacina estudantes" (POLÍCIA DE NEGRÃO..., 1968, p. 01). Estas são algumas das manchetes publicadas pelos periódicos Folha de S. Paulo (edições matutina e vespertina) e Jornal do Brasil no dia posterior à morte de Edson Luís de Lima Souto, respectivamente. Elas anunciam o agente da ação, destacam o protagonismo dos estudantes e sublinham o valor social do acontecimento.

Em 28 de março de 1968, os jovens que realizavam suas refeições no Restaurante Central dos Estudantes, o Calabouço, localizado na região central do Rio de Janeiro, foram repreendidos pela polícia militar enquanto organizavam uma manifestação pela melhora no serviço e nas condições físicas do prédio. Um edifício anterior fora demolido em 1967, sob a justificativa de ali serem realizadas obras de infraestrutura urbana para melhoria do trânsito. 
Folha de S. Paulo e Jornal do Brasil (JB), dois veículos de grande circulação naquele período histórico e sedeados nas duas principais capitais do país, São Paulo e Rio de Janeiro, respectivamente, são os materiais que utilizamos a fim de nos aproximarmos do clima que se instaurou após as cenas de repressão ocorridas naquele dia. Suas capas apontam para a construção do acontecimento como um assassinato, como mostram as manchetes que transcrevemos no início desta seção. No $J B$, o termo é utilizado de forma explícita. Além disso, uma fotografia do jovem morto deitado sobre uma mesa, coberto com bandeiras e cartazes, rodeado por outros estudantes, estampa o topo da página, logo acima da manchete.

No caso da Folha, a capa publicada no período da manhã não traz fotografias ou textos sobre o assunto, contendo apenas a manchete na parte superior. O distanciamento geográfico, quando comparado com o $J B$, influencia no conteúdo apresentado pelo jornal, bem como na falta de impacto visual. Mesmo assim, é dado destaque para a morte. Na edição da tarde, a manchete passa a ser mais explícita: ao mesmo tempo em que atribui um peso de responsabilidade ao governo/governador estadual, humaniza e aproxima o leitor dos estudantes, especialmente por meio de fotografias. Ainda na capa, é noticiado que representantes da imprensa sofreram violência. Os textos na parte interna dos cadernos dão relevância ao papel da, e à violência contra, a imprensa naquele dia.

Édson Luís de Lima Souto foi carregado nos braços por estudantes. Foi um corpo defendido e utilizado como escudo para, primeiro, entrar na Santa Casa de Misericórdia, ao lado do Calabouço, e, depois, ser resguardado no prédio da Assembleia Legislativa, então localizada na Cinelândia. Autopsiado e velado ali, sua camisa foi utilizada como bandeira, símbolo da violência.

Na capa do $J B$ é possível percebermos um dos primeiros fios dessa construção: as duas fotografias utilizadas na composição retratam a centralidade do corpo inerte e da camisa ensanguentada. Os estudantes usam bandeiras e cartazes para cobrir parte do corpo. De acordo com o texto, existiriam ao menos duas versões para o que chamam de "atrito":

[...] 1) estes [estudantes] jantavam pacificamente, enquanto outros assistiam uma aula, quando um choque da PM, chefiado por um tenente de nome Alcino ou Costa, invadiu o restaurante e iniciou o espancamento, ao qual os estudantes reagiram com pedras que, por sua vez, provocaram tiros; 2) os estudantes teriam sido colhidos pela PM, em plena manifestação contra o atraso na conclusão das obras do restaurante (ASSASSINATO..., 1968, p. $01)$.

No dia seguinte, um cortejo levou o corpo ao Cemitério São João Batista, em um 
caixão carregado por estudantes por cerca de seis quilômetros. A camisa, símbolo do acontecimento e bradada como referência enquanto os estudantes ainda estavam em sua posse, é substituída durante a manifestação por um nome, por um filho que "poderia ser o seu", por um caixão. Edson Luís representa a fúria da ditadura contra os estudantes. Sua morte é associada ao recrudescimento do sistema: a promulgação do Ato Institucional $\mathrm{n}^{\circ} 5$ (AI-5), em 13 de dezembro.

No entanto, cabe destacar algumas incoerências que cercam a narrativa da morte do jovem nas poucas horas que separam o acontecimento e a publicação dos jornais. O choque aconteceu pouco depois das $18 \mathrm{~h}$, sendo $18 \mathrm{~h} 30$ apontada, em consenso pelos periódicos, como a hora da morte do estudante, após disparo realizado à queima-roupa. Um dos elementos que se destaca na narrativa são os nomes. O próprio nome Édson Luís de Lima Souto, forma replicada à exaustão em livros de memórias e de história, não é consenso naquele 29 de março. É possível ver referências ao jovem com mais de um nome. Édson, Nélson e Nilton são as principais formas. Segue trecho extraído da edição matutina da Folha de S. Paulo, jornal que apresenta a maior variedade de citações ao estudante, com nomes diversos:

Vários deputados resolveram manter-se em sessão permanente na Assembleia Legislativa, para impedir a invasão policial. Os oradores condenaram a violência policial. A camisa ensanguentada do estudante Nelson Luís Souto foi agitada como bandeira utilizada para angariar fundos com os quais serão realizados os funerais do jovem (NA ASSEMBLEIA..., 1968, p. 14).

Na construção do personagem, alguns elementos são reiteradamente utilizados, como é o caso da camisa ensanguentada. Nos dois periódicos há alusões ao objeto. De acordo com o Jornal do Brasil, "a camisa de Édson Luís, que chegou a ser utilizada como estandarte na noite de ontem, foi recolhida para perícia pelos policiais da $3 .^{a} \mathrm{DD}$, a quem ficará afeto o caso. Depois de entrega-la à Polícia, os estudantes saíram em busca de uma outra para vestir o corpo" (POLÍCIA MATA..., 1968, p. 05).

Há também controvérsias no que tange à idade da vítima. A dúvida deveria ter sido sanada ao examinarem um documento que afirma que o garoto havia nascido em 24 de março de 1950. Contudo, na mesma página do $J B$ onde pode ser encontrada a informação, também é dito que ele tinha 16 anos. Ainda de acordo com o jornal, "o endereço de Édson, que em sua ficha do Instituto Cooperativo de Ensino constava como Rua Cairuçu, 302, Vila Valqueire, não confere. O número da casa não existe, e ninguém, naquele local, conhecia o estudante" 
(POLÍCIA MATA..., 1968, p. 05). As contradições se seguem: os textos no $J B$ ainda afirmam que ele moraria com um irmão, mas dizem também que os demais estudantes alegam que ele era muito pobre e, na maioria das vezes, dormia no anexo do Calabouço.

O último ponto de significativo desencontro de informações que aqui destacamos diz respeito ao incidente que levou ao choque entre policiais e estudantes. Neste caso, pode-se perceber que as múltiplas versões se dão por duas vias: os militares tentam justificar o ocorrido, ao passo que os estudantes temem que o fato seja distorcido pelos oficiais. Em fala na Assembleia Legislativa, segundo versão reproduzida nos dois periódicos, teria ocorrido o seguinte diálogo entre o general Osvaldo Niemayer e o deputado Márcio Moreira Alves, do Movimento Democrático Brasileiro (MDB):

Durante a sua presença na Assembleia Legislativa, o general Osvaldo Niemair [sic], demitido das funções de superintendente da Polícia Executiva, afirmou:

A polícia agiu assim porque estava em inferioridade em potencia de fogo"

A isto indagou o deputado Marcio Alves:

"Potência de fogo? É a arma?"

Respondeu o general:

"É tudo aquilo que nos agride, era pedra. Foram vistos vários clarões.

Insistiu o deputado:

"Foram ouvidos ruídos?"

Respondeu o general:

"Não foram ouvidos, mas ouvi tiros em seguida" (POLÍCIA DA GUANABARA..., 1968, p. 03).

O texto explicita a contradição naquela explicação, em uma época em que os jornais ainda possuíam certa liberdade para falar daquilo que acontecia no país. Segundo a versão oficial, conforme apresentado no extrato anterior, a polícia teria reagido ao ataque que sofrera por parte dos estudantes. Além do fato de não haver uma versão única para os tiros disparados, ainda há discordância quanto ao motivo da reunião dos estudantes, tanto no que aparece nos jornais quanto no que é retomado nos livros: eles poderiam estar organizando uma passeata a favor do Vietnã ou dando início a uma manifestação em prol de melhores condições no restaurante, sendo estas as versões dos militares e dos estudantes, respectivamente. Segue a versão defendida pelos estudantes e publicada pelos jornais: 
À medida que invadiam o restaurante, os policiais, que eram comandados por um tenente ou aspirante alto e gordo, de nome Alcindo ou Costa, iam atacando a todos, indiscriminadamente, com cassetetes, inclusive o professor que dava aula no Instituto Cooperativo de Ensino, ali instalado. Os estudantes $\log$ o se organizaram e passaram a revidar à agressão com pedradas. Foi nesse momento que o tenente comandante do pelotão sacou um revólver e atirou, atingindo Édson Luís de Lima Souto, que, em companhia de Benedito Frazão Dutra, assistia à aula (POLICIA MATA..., 1968, p. 05).

De acordo com a construção realizada pelos jornais, é possível compreender que, entre os consensos, estavam principalmente as desconfianças dos estudantes. Ambos os jornais afirmam que eles não permitiram que o corpo de Edson Luís fosse para o Instituto Médico Legal, por exemplo, por receio de que os militares se desfizessem das provas. Em diálogo com as suspeitas que são colocadas pelos estudantes, o jornal paulista relata a reação das autoridades acerca do movimento estudantil em São Paulo:

O DOPS elaborou amplo relatório não só dos fatos que vitimaram o estudante Nelson Luís Souto, como também da situação dos estudantes em São Paulo [...] De posse desses informes, o secretário da Segurança procurou o governador para debater a questão, as providências que deverão ser tomadas em São Paulo, no caso de nova agitação no meio estudantil [...] (POLICIA DA GUANABARA..., 1968, p. 03).

Estes relatórios seriam úteis. Em outubro, por exemplo, foram dois os grandes acontecimentos envolvendo os estudantes de São Paulo. Primeiro, a Batalha da Maria Antônia, no início do mês. Poucos dias depois, o XXX Congresso da UNE. Neles, estudantes foram presos e José Guimarães, também secundarista, morto.

Até aqui, observamos o que foi publicado à época por dois jornais do país. Grande enfoque é dado à irresponsabilidade que causou a morte do estudante, bem como aos acontecimentos que estavam sendo desencadeados a partir daquele assassinato. Passamos, agora, a tratar da forma como o personagem Edson Luís e sua morte foram retratados com a passagem dos anos e o fim da ditadura militar no país.

\section{A construção e as disputas pela memória}

Aproximando-nos de textos publicados anos depois da morte do secundarista, podemos perceber como se deu a construção, em um contexto de batalha pela memória, daquele acontecimento. No que tange a livros que tratam do ano de 1968 de uma forma 
ampla, optamos por lançar nosso olhar sobre 1968: o ano que não terminou, de Zuenir Ventura, publicado originalmente em $1989^{2}$, e 1968: eles só queriam mudar o mundo (2008), de Regina Zappa e Ernesto Soto, livros de jornalistas que, dada sua expressividade, foram republicados em 2018. Especificamente sobre os acontecimentos da Guanabara, elegemos Calabouço 1968: o cerco das trevas (1986), de Josué Diniz, como material de referência, único livro de testemunho do acontecimento publicado.

O capítulo do livro no qual Zuenir Ventura trata da morte do estudante é intitulado "Onde tudo começou", em referência ao ponto inicial dos acontecimentos que culminaram no AI-5. Afirma Ventura (2008, p. 93): “O Rio de Janeiro já foi uma cidade capaz de parar numa sexta-feira à tarde para enterrar um estudante morto pela PM". O texto original, publicado quatro anos após o fim da ditadura, demonstra certo descrédito, por parte do autor, em relação [às ações protagonizadas pelos estudantes e pela adesão da população do Rio ao movimento]. Ventura destaca, agora com a liberdade necessária, alguns dos temores dos estudantes:

Logo depois de baleado, provavelmente já morto, Edson Luís foi levado pelos colegas à Santa Casa de Misericórdia, vizinha do Calabouço, para evitar que a polícia sequestrasse o corpo. Confirmada a morte, os estudantes ergueram o cadáver nos braços e, usando-o como aríete, foram empurrando os policiais até a Assembleia (VENTURA, 2008, p. 93-94).

A narrativa de Ventura ainda lança luz sobre uma das inconsistências que permeia os textos publicados logo após o choque. Segundo os primeiros escritos de 1968, haveria dois estudantes mortos. O jornalista traz, para explicar esta inconsistência, um novo personagem: o médico e deputado Jamil Haddad, que o texto afirma ser então ligado ao Partido Socialista Brasileiro (PSB), clandestino. Segundo Ventura, enquanto Edson Luís estava sem vida, o outro encontrava-se em estado de choque. Ainda sobre o clima de desconfiança no qual imergiam os estudantes, narra Ventura (2008, p. 95): "Mais trabalho do que ressuscitá-lo talvez tenha sido convencer seus colegas de que o carro da Assembleia que saíra em seguida para o Hospital Souza Aguiar, levando Benedito Frazão Dutra, ferido, não estava sequestrando um morto".

No mosaico de memórias que Ventura aciona para traçar os acontecimentos, Sobral Pinto é chamado de "advogado da liberdade" por Elinor Brito, presidente da Frente Unida dos Estudantes do Calabouço (FUEC), em março de 1968. Os relatos dos personagens expostos no livro de Ventura, contudo, expõem a contradição dos estudantes àquilo que, à época, foi recomendado por Sobral Pinto: entregar o corpo para o IML. Para embasar a possibilidade de

\footnotetext{
${ }^{2}$ Para fins desta análise, será utilizada a versão reeditada em 2008.
} 
autópsia na Assembleia, um estudante afirmou que "Getúlio Vargas, outra vítima do poder econômico, também foi autopsiado fora do Instituto Médico Legal” (VENTURA, 2008, p. 95).

A narrativa de Ventura (2008) afirma que os jovens deputados do Movimento Democrático Brasileiro (MDB) que faziam parte do Grupo Renovador, de esquerda, foram os responsáveis por manter diálogo com os estudantes. Ciro Kurtz, Alberto Rajão e Fabiano Villanova são indicados como principais mediadores da situação. Em meio às negociações, mais uma modificação nas feições de personagens com a passagem dos anos. Negrão de Lima, governador do Estado da Guanabara, é descrito como alguém que havia perdido o controle e estaria insatisfeito com isso:

Kurtz e Villanova se dispuseram a ficar negociando com as lideranças estudantis, enquanto Rajão se dirigia ao Guanabara, onde encontrou o governador prostrado, reclamando de sua falta de autoridade. Eleito pela oposição em 66, Negrão tivera dificuldades em assumir, e governava debaixo de pressões: das forças oposicionistas que o elegeram e da linhadura (VENTURA, 2008, p. 96).

Ao descrever o enfrentamento entre estudantes e policiais, Ventura afirma que foi uma reação às manifestações que estavam sendo preparadas pelos estudantes. Contudo, encontramos mais uma informação que diverge daquela publicada no dia seguinte à morte do estudante. Trata-se do personagem que seria o autor do disparo: "Sem horário de verão, às seis horas da tarde já era noite, o que impediu que as testemunhas vissem que o tiro saía do revólver do aspirante da PM Aloísio Raposo para atingir mortalmente o coração do estudante Edson Luís" (VENTURA, 2008, p. 99). O jornalista, contudo, não explica como teria chegado a esse nome. Na narrativa de Zappa e Soto (2008), em diálogo com as informações publicadas no dia seguinte ao acontecimento, o tiro foi disparado pelo tenente Alcindo Costa, comandante da tropa.

Após vinte anos, é possível para Ventura afirmar que aquele foi um importante ponto de virada para a construção da memória do movimento estudantil e de 1968, bem como de Edson Luís como um personagem importante:

Longe de ser um líder, Edson Luís era, como muitos de seus colegas, um daqueles jovens que vinham do interior tentar estudar no Rio, sobrevivendo graças à alimentação barata do Calabouço. Para estudar, Edson Luís era obrigado a recorrer a pequenos expedientes, inclusive na limpeza do restaurante. Ele não tinha nenhum dos componentes míticos para sonhar em ser o que acabou sendo: um mártir (VENTURA, 2008, p. 99). 
Sem que haja unanimidade em torno dos acontecimentos daquele fim de tarde, na memória da ditadura no país Edson Luís é um mártir, sem ter defendido qualquer tipo de posicionamento político. Foi essa morte que chamou atenção, que foi utilizada como forma de atrair o povo para a luta contra o governo ditatorial. Em um balanço geral da situação que em sua leitura foi, em partes, desencadeada pela morte do estudante, "pode-se dizer que tudo começou ali - se é que se pode determinar o começo ou o fim de algum processo histórico. De qualquer maneira, foi o primeiro incidente que sensibilizou a opinião pública para a luta estudantil [...] 'era o cadáver que faltava"” (VENTURA, 2008, p. 100). Visão semelhante é compartilhada por Zappa e Soto (2008):

O assassinato de Edson Luís indignou o país e marcou o início de um período de enorme agitação e crescente violência que iria se estender por todo o ano. No dia seguinte ao enterro, explodiram manifestações de protesto em diversas capitais. Algumas delas fugiram ao controle de seus organizadores e terminaram em enfrentamentos com dezenas de feridos (ZAPPA; SOTO, 2008, p. 73).

Os autores ainda estampam uma fotografia de Edson Luís deitado sobre a mesa, rodeado por estudantes e coberto por bandeiras e cartazes, trazendo na legenda a informação de que aquela morte indignou todo o país. Os jornalistas fazem referência às manchetes publicadas pelos jornais cariocas no dia seguinte, nas quais os veículos chamam a ação de assassinato e fuzilamento, contribuindo para o clima de indignação que se instaurou.

Uma visão completamente diferente dos fatos nos é apresentada nas memórias de Josué Diniz (1986). Estudante e militante de esquerda em 1968, o autor desconstrói a imagem de alguns personagens, como é o caso do então presidente da FUEC, Elinor Brito. Diniz opta por não citar os nomes verdadeiros dos personagens que aparecem em sua narrativa. Contudo, é possível identificar que o personagem chamado Hector é Elinor. Diniz (1986) começa a narrativa em 1967, quando os estudantes são informados da demolição do antigo restaurante, e termina com a morte de Edson Luís e o encerramento das atividades do Calabouço.

Aqui cabe realizarmos uma pequena análise sobre o papel da memória quando nos referimos a narrar o ano de 1968. A memória tende a buscar as justificativas, aquilo que levou à importância que esse ano possui para a história do país e do mundo. A reorganização do movimento estudantil, que vinha se recuperando da perseguição às instituições nacionais, e o surgimento da FUEC em 1967 são colocados por Diniz (1986) como elementos fundamentais para entendermos o "perigo" que representavam as manifestações protagonizadas pelos 
secundaristas. A morte do estudante representou a asfixia do movimento. Ao ter fim o sonho de Edson Luís, tinha início a repressão ao sonho de outros estudantes. No relato memorialístico de Diniz (1986), a morte é, também, do movimento estudantil e do ano de 1968.

Com quase vinte anos para rememorar e reorganizar as lembranças, Diniz (1986) constrói a imagem do então presidente da FUEC como um personagem que se aproveitou dos anseios dos estudantes para ser alçado como líder, além de apontar determinados fatos que ligariam o jovem com as forças da repressão. Sobre a chegada de Hector/Elinor ao Calabouço, em uma manhã de sábado, afirma o texto: “A partir daquele momento tínhamos um novo líder [...] que, em apenas uma hora e meia, invadira o restaurante, falara da criação da FUEC, fazendo em seguida a votação para que sua manobra tivesse uma conotação democrática" (DINIZ, 1986, p. 44). Diniz lembra que buscaram entender quem era aquele personagem, procurando por informações nas instituições de ensino da cidade, e não descobriram seu vínculo, questionando seu valor como líder estudantil.

Sobre a ascensão de Hector/Elinor, Diniz (1986, p. 47) afirma que aquela foi “[...] a primeira vitória da ditadura militar sobre os estudantes". O personagem, que aparece nas demais narrativas como a voz dos estudantes, como um sujeito que defende os interesses da classe, nas memórias de Diniz desarticula o movimento estudantil. Segundo o relato, essa era a impressão dos comensais do Calabouço.

Ao inserir Edson Luís na narrativa, Diniz o apresenta como aquele que talvez fosse o mais novo dos frequentadores do restaurante, afirmando que ele tinha 16 anos. Outra informação importante diz respeito a sua vinculação política: “[...] não participava de nenhuma facção do movimento estudantil e nunca fora visto carregando uma faixa ou um cartaz, numa passeata" (DINIZ, 1986, p. 94). O principal destaque que damos às informações trazidas por Diniz diz respeito a uma desconfiança que não foi tratada em nenhuma das demais obras: Edson Luís seria um espião do Departamento de Ordem Política e Social (DOPS). 
- Quero denunciar aqui o Edson! O companheiro é acusado de ser informante do DOPS! Se hoje o companheiro não sair à frente da passeata será banido do Calabouço, pois não admitiremos dedo-duro da polícia em nosso movimento!

Houve um breve silêncio. Todos os olhares se convergiram para Edson, que permanecia onde estava sem dizer uma palavra. Iniciávamos a nossa saída do pátio do Calabouço, quando, de repente, uns cinquenta policiais, portando metralhadoras, irromperam ali, disparando em todas as direções. Os estudantes corriam, procurando se abrigar. Bem de frente para os policiais estava o jovem Edson, com duas pedrinhas nas mãos (DINIZ, 1986, p. 97).

Edson, rapaz pobre do Norte, que não possuía dinheiro para pagar pelas aulas e que ninguém sabia ao certo onde morava, é apontado como informante do DOPS, uma acusação que não perdurou. Segundo as narrativas daquela noite, especialmente as publicadas nos livros de jornalistas, o presidente da FUEC fez discursos inflamados sobre a retidão do jovem, sobre a brutalidade com a qual a polícia o assassinou. As memórias de Diniz (1986) ainda trazem algumas informações sobre a atuação dos estudantes, como, por exemplo, os acontecimentos dentro da Santa Casa. Se os demais relatos se limitam a dizer que recusaram atendimento ao estudante, Diniz traça um quadro mais específico:

No hospital, uma surpresa nos aguardava. Os médicos não quiseram atender o ferido. Edson respirou pela última vez. Nós o colocamos no saguão do hospital e, em seguida, passamos a espancar médicos, freiras. Quebramos os vidros das portas, janelas, tombamos arquivos, rasgamos fichas. Saímos dali com Edson já morto, nas costas de três companheiros (DINIZ, 1986, p. 98).

As manifestações daquela tarde eram organizadas desde o início do mês, em local por onde passavam cerca de sete mil pessoas por dia. Era esperado que a polícia tivesse informações e tentasse conter a manifestação. O detalhe, na narrativa de Diniz, contudo, chama atenção para a forma como a morte do estudante passa a ser gratuita. Não há qualquer menção ao choque: "Edson não se moveu. O guarda de trânsito sacou seu revólver e, numa distância de dois metros de onde estava o Edson, disparou um tiro certeiro em cima do peito do jovem que, no mesmo instante, caiu no chão como se fosse um saco de pedras" (DINIZ, 1986, p. 97). 


\section{Algumas considerações}

A construção da memória é um processo conflituoso. A percepção desse movimento leva a vislumbrar os conflitos que estavam presentes entre os atores à época do assassinato de Edson Luís, bem como pode fazer perceber os processos que foram desencadeados após os acontecimentos. Do ponto de vista social, as percepções que se tem daquilo que foi presenciado no passado pode sofrer alterações. Maturadas pelo tempo, as experiências revelam facetas não apontadas anteriormente. Se olhamos para um distanciamento de 50 anos, também trabalhamos com um cenário em que muitos dos sujeitos que vão ter acesso às memórias não eram nascidos, estão colocados em meio a um mosaico de representações sociais que balizam o entendimento que vão ter dos acontecimentos, dos personagens, do encadeamento da história.

Entre as fontes de que nos aproximamos aqui, é possível traçar considerações acerca das disputas de poder em torno do caso Edson Luís. Após a morte do estudante, os jornais deram espaços diferenciados para as duas versões do acontecimento. Isso nos faz perceber o valor político que tinha a imprensa e a justificativa para a asfixia que viria meses depois, com a edição do AI-5 e a censura prévia. Mesmo quando os jornais apresentam a justificativa policial, ela é contestada por outra figura pública, Márcio Moreira Alves. As leituras da imprensa serão acionadas novamente quando da construção das memórias: capas de jornal, fotografias e textos se colocam em disputa. Reinterpretadas, são ferramentas para o enquadramento das memórias.

Em contrapartida, o testemunho também é usado como arma contra as memórias já construídas. Josué Diniz discorda dos passos consolidados pelas demais narrativas, sendo sufocado pelo poder do tempo e da memória. A leitura que prevalece está conectada com as visões de Ventura (2008), Zappa e Soto (2008): com o distanciamento do tempo, o espaço para rever os acontecimentos, a pesquisa e a publicação de entrevistas e memórias pessoais, eles refletem parte daquilo que está posto no plano social, na memória dita coletiva.

A marcação emocional da construção da memória é algo que se destaca ao juntarmos as peças desse jogo. Em 1968, parte da imprensa apoiava as manifestações contrárias ao regime ditatorial. Se em 1964 haviam consentido com o golpe militar, em 1968 já existia desconfiança em relação à ditadura. Ventura era jornalista em 1968, mantinha contatos na imprensa e fora dela. Enfrentava os entraves do governo ditatorial. Zappa, por sua vez, era adolescente, tinha 14 anos, mas afirma lembrar-se da emoção que sentiu, justamente, por 
ocasião do enterro de Edson Luís. Uma lembrança que ficou marcada, que reverbera. Na contramão, temos Diniz, então estudante, militante de esquerda, cuja memória diverge das demais e tenta fincar novas marcas na história.

Memória é disputa. Edson Luís é, hoje, um personagem construído e cuja construção perpassa aquilo que é publicado sobre ele em narrativas midiáticas. Não era militante ou participava de manifestações, era pobre e buscava educação e mudança de vida. Esta construção começou desde o momento seguinte a sua morte. $\mathrm{O}$ acontecimento foi utilizado, à época, como forma de sensibilizar o povo e trazê-lo para as manifestações, colocá-lo contra a ditadura. $\mathrm{O}$ que reverbera nos textos posteriores é parte daquilo que ficou dos jornais, quando Edson Luís já era considerado mártir. Em um cenário em que a polícia tentava justificar a ação, o que temos na memória compartilhada é um personagem cuja morte culminou no recrudescimento do regime. A construção do personagem Edson Luís faz parte da memória referente à ditadura militar, à luta contra a repressão. No entanto, foram os enquadramentos dados à memória que deram a ele esse status, mais do que sua participação no movimento. 
Referências

ASSASSINATO leva estudantes à greve nacional. Jornal do Brasil, Rio de Janeiro, p. 1, 29 mar. 1968.

BABO-LANÇA, Isabel. Acontecimento e memória. In: FRANÇA, Vera Regina Veiga; OLIVEIRA, Luciana de (org.). Acontecimento: reverberações. Belo Horizonte: Autêntica Editora, 2012. p. 55-65.

BABO-LANÇA, Isabel. A constituição do sentido do acontecimento na experiência pública. Trajectos, Revista de Comunicação, Cultura e Educação, Lisboa, n. 6, p. 85-94, 2005.

DINIZ, Josué Alves. Calabouço 1968: o cerco das trevas. Rio de Janeiro: Livraria Editora Cátedra, 1986.

ESTUDANTE morto em choque no Rio. Folha de S. Paulo, São Paulo, p. 1, 29 mar. 1968.

HALBWACHS, Maurice. A memória coletiva. São Paulo: Centauro, 2003.

JELIN, Elizabeth. Los trabajos de la memoria. Madrid: Siglo Veintiuno de España Editores, 2002.

NA ASSEMBLEIA o corpo do estudante morto em choque com a policia carioca. Folha de S. Paulo, São Paulo, p. 14, 29 mar. 1968.

POLÍ́CIA DA GUANABARA mata estudantes. Folha de S. Paulo, São Paulo, p. 3, 29 mar. 1968. Edição da tarde.

POLÍCIA DE NEGRÃO chacina estudantes. Folha de S. Paulo, São Paulo, p. 1, 29 mar. 1968. Edição da tarde.

POLÍCIA MATA estudante em choque no Calabouço. Jornal do Brasil, Rio de Janeiro, p. 5, 29 mar. 1968.

POLLAK, Michael. Memória, esquecimento, silêncio. Estudos Históricos, Rio de Janeiro, v. 2, n. 3, p. 3-15, 1989.

VENTURA, Zuenir. 1968: o ano que não terminou. 3. ed. São Paulo: Editora Planeta do Brasil, 2008.

ZAPPA, Regina; SOTO, Ernesto. 1968: eles só queriam mudar o mundo. Rio de Janeiro: Jorge Zahar, 2008.

Submetido em 02.08.2018

Aprovado em 23.12.2019 